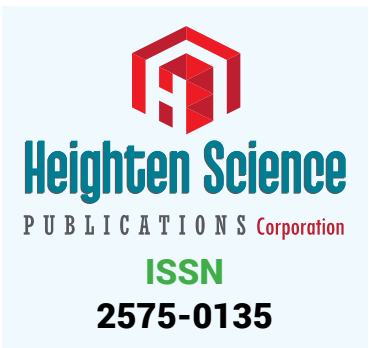

*Address for Correspondence: Shu Wei, State Key Laboratory of Tea Plant Biology and Utilization, Anhui Agricultural University, 130 Changjiang Ave W, Hefei, Anhui, 230036, China, Tel \& Fax: +86-551-65783941; Email: weishu@ahau.edu.cn

Submitted: 27 May 2017

Approved: 09 June 2017

Published: 12 June 2017

Copyright: @ 2017 Rana MM, et al. This is an open access article distributed under the Creative Commons Attribution License, which permits unrestricted use, distribution, and reproduction in any medium, provided the original work is properly cited.

Keywords: A. Rhizogenes; Hairy root; Virulence; GUS

\title{
Wild-type Agrobacterium rhizogenes- mediated gene transfer in plants: Agrobacterium virulence and selection of transformants
}

\author{
Mohammad M Rana', ${ }^{1,2}$ Muhammad Abdullah' ${ }^{1}$, Ferdinand L \\ Shamalla ${ }^{1}$ and Shu Wei ${ }^{1 *}$ \\ 'State Key Laboratory of Tea Plant Biology and Utilization, Anhui Agricultural University, 130 \\ Changjiang Ave W Hefei, Anhui 230036, China \\ ${ }^{2}$ Bangladesh Tea Research Institute, Srimangal-3210, Moulvibazar, Bangladesh
}

\section{ABSTRACT}

Agrobacterium rhizogenes ATCC 15834 wild type strain was transformed with the binary vector $\mathrm{pBI} 121$ using the heat shock method. The transformed Agrobacterium was then tested for virulence through tobacco leaf explant transformation. Compared to the non-transformed Agrobacterium, the transformed Agrobacterium showed reduced virulence, producing significantly lower number of hairy roots in tobacco leaf explants. Although the transformed Agrobacterium showed reduced virulence, it was able to transfer the T-DNA of the binary vector into the plant genome, resulting in stable GUS expression in the generated hairy roots. This indicated that in addition to the transfer DNA (T-DNA) from its root inducing (Ri) plasmid, the transformed Agrobacterium is also capable of transferring the binary vector T-DNA and allowing the integration of a foreign gene. Results also showed that hairy root generation efficiency of the transformed Agrobacterium varied with the concentration of the selection agent (kanamycin). Hairy root generation efficiency (hairy roots explant ${ }^{-1}$ ) progressively increased with decreasing concentrations of kanamycin; and the efficiency was highest in the absence of kanamycin. Generated hairy roots showed very strong to tiny GUS expression even those that grew under the highest concentration of the kanamycin $\left(50 \mathrm{mg} \cdot \mathrm{L}^{-1}\right)$. This indicated that co-transformation and efficient transgene expression does not always occur.

\section{INTRODUCTION}

Agrobacterium-mediated genetic transformation is the most widely used method of transferring genes into plants [1]. Besides being cheaper and simpler than most direct gene transfer methods, it reduces the rearrangement of transgenes, and efficient integration of the transgene into the plant genome [2]. Agrobacterium rhizogenes is a Gram-negative, rod-shaped soil bacterium [3], which is a close relative of the best-characterized species A. tumefaciens among the genus Agrobacterium [4]. All A. rhizogenes strains are characterized by the presence of a large root inducing (Ri) plasmid [5]. Following A. rhizogenes infection, hairy root formation occurs directly from the infection site in the form of large numbers of small protruding roots resembling fine hairs [6]; the genomic integration of a set of genes (encoding enzymes involved in auxin and cytokinin biosynthesis) is mediated through a specific transfer DNA (T-DNA) from the Ri plasmid [7]. A. rhizogenes-induced roots have the unique property of being able to grow in vitro without exogenous plant growth regulators $[8,9]$.

Hairy-root cultures have several properties that have promoted their use for plant biotechnological applications. These roots are also characterized by their genetic stability [10]. Their fast growth, short doubling time, ease of maintenance, and ability 
to synthesize a range of chemical compounds and proteins offer hairy roots advantages over plant cell suspension cultures as a continuous source for the production of valuable secondary metabolites and foreign proteins [4]. Hairy root cultures are usually able to produce the same compounds found in wild-type roots of the parent plant, but without the loss of concentration frequently observed with callus or cell suspension cultures [11]. Using these features of A. rhizogenes, a broad range of difficulties in in vitro plant tissue and organ cultures were eliminated, and it became possible to generate fast growing organs with the capability of producing more metabolites even at higher concentrations than in the mother plant $[12,13]$.

Apart from this, the ability of $A$. rhizogenes to transfer the disarmed T-DNA region from the A. tumefaciens-based binary vector along with the T-DNA from Ri plasmid has been exploited to develop co-transformed transgenic hairy root culture [14]. The co-transformed hairy roots are an extremely powerful tool for rapid and reproducible research in diverse areas including the establishment of gene function [15], analysis of promoter activity [16], heterologous protein expression [17], antibody production [18], modification of plant metabolic pathways [19] and functional genomics studies [20]. In addition, composite plants can be developed [21]; transformed hairy roots can also be used to produce stable transgenic plants, which have already been reported in some plants including Crotalaria [22], Medicago [23], Alyssum [24] and Plumbago [25].

Importantly, the T-DNA from Ri plasmid and the disarmed T-DNA region from the A. tumefaciens-based binary vector independently integrates into the plant genome. Thus, the transgenic plant regenerated from a transgenic hairy root culture allows segregation of the two T-DNAs during meiosis and transgenic plant lines with only the binary vector derived T-DNA can be obtained in the filial progeny [26]. The abovementioned advantages have made A. rhizogenes a promising agent for plant genetic engineering; at least for those plants that are recalcitrant or less-responsive to the $A$. tumefaciens-mediated plant transformation. However, insertion of a foreign plasmid into the wild-type A. rhizogenes strain might have some impact on its virulence due to the involvement of two plasmid simultaneously during the transformation process. In addition, some other events can also happen like T-DNA from either the plasmids or any of the plasmids can be transferred and integrated into the plant genome that will lead different consequences. Therefore, this basic study was conducted using the model plant tobacco and wild type A. rhizogenes ATCC 15834 strain to understand the impact of insertion of a foreign plasmid into this wild-type strain and to optimize the selection process of the transformants.

\section{MATERIALS AND METHODS}

\section{Bacterial strains and transformation vector}

The binary vector pBI121 used in this study was purchased from Clontech (Beijing, China). The vector contained gusA and nptII, as reporter and selective genes, respectively. Escherichia coli strain DH5 $\alpha$ was used to amplify the plasmid pBI121 in small scale. Agrobacterium rhizogenes strain ATCC 15834 was used for the transformation study. Both bacterial strains were obtained from Lab 263, Sate Key Laboratory of Tea Plant Biology \& Utilization, Anhui Agricultural University, Hefei, Anhui, China.

\section{Bacterial transformation}

The binary vector pBI121 was first introduced into E. coli strain DH5 $\alpha$ following standard protocol to amplify the plasmid in small scale. The plasmid was then extracted from E. coli and finally introduced into the Agrobacterium following heat shock method. Successful transformation of Agrobacterium was confirmed through PCR. For the PCR, $1 \mu \mathrm{L}$ bacterial culture was used as template for each reaction mixture $(25 \mu \mathrm{L})$. Positive and negative controls consisted of $1 \mu \mathrm{L}$ plasmid DNA ( 50 ng) and $1 \mu \mathrm{L} \mathrm{ddH_{2 }} \mathrm{O}$, 
respectively. The primer sequences of 35S (Forward), 5'-CAATCCCACTATCCTTCG CAAGACCC-3' and NOS (Reverse), 5'-GATCTAGTAACATAGATGAC ACCG-3' were used to amplify a fragment length of 2239-bps from pBI121. PCR was performed in a 25 $\mu \mathrm{L}$ reaction volume containing 1 Unit of Easy-Taq DNA Polymerase, $1 \mu \mathrm{L}$ of bacterial culture, $1 \mu \mathrm{L}$ of each primer $\left(10 \mathrm{mM} \cdot \mathrm{L}^{-1}\right), 2.5 \mu \mathrm{L} 10 \times$ buffer, $2 \mu \mathrm{L} \mathrm{dNTP}\left(2.5 \mathrm{mM} \cdot \mathrm{L}^{-1}\right)$, and $17.5 \mu \mathrm{L}$ water. Amplification was performed in a programmable Thermal cycler (BioRad S1000) as follows: initial denaturation at $95^{\circ} \mathrm{C}$ for $5 \mathrm{~min}, 30$ cycles of amplification (denaturation at $95^{\circ} \mathrm{C}$ for $30 \mathrm{~s}$, annealing at $55^{\circ} \mathrm{C}$ for $30 \mathrm{~s}$, and extension at $72^{\circ} \mathrm{C}$ for $2 \mathrm{~min} 30 \mathrm{~s}$ ) and a final extension of $72^{\circ} \mathrm{C}$ for $10 \mathrm{~min}$. After amplification, the samples were resolved by DNA gel electrophoresis (Figure 1). Finally, the verified positive Agrobacterium (transformed with pBI121) culture was preserved at $-80^{\circ} \mathrm{C}$ for further use.

\section{Tobacco transformation}

To compare the virulence of the transformed A. rhizogenes with wild-type, and to check the ability of the transformed Agrobacterium to transfer and integrate the binary vector T-DNA into the plant genome, the tobacco leaf explant transformation experiment was carried out. Tobacco leaf explants were inoculated separately using both wild-type and transformed Agrobacterium. Hairy root generation efficiency of the transformed Agrobacterium was also tested under different selective pressures (i.e. different concentrations of the antibiotic kanamycin). In brief, the treatments included are: (T0) Wild-type Agrobacterium $+0 \mathrm{mg} \cdot \mathrm{L}^{-1}$ kanamycin; (T1) Transformed Agrobacterium $+0 \quad \mathrm{mg} \cdot \mathrm{L}^{-1}$ kanamycin; (T2) Transformed Agrobacterium +12.5 $\mathrm{mg} \cdot \mathrm{L}^{-1}$ kanamycin; (T3) Transformed Agrobacterium+25.0 $\mathrm{mg} \cdot \mathrm{L}^{-1}$ kanamycin; (T4) Transformed Agrobacterium $+37.5 \mathrm{mg} \cdot \mathrm{L}^{-1}$ kanamycin, (T5) Transformed Agrobacterium $+50.0 \mathrm{mg} \cdot \mathrm{L}^{-1}$ kanamycin.

\section{Experimental design}

The experiment was carried out in a completely randomized design with three replications. Each replication consisted of a single Petri plate containing 10-15 leaf explants.

\section{Preparation of media}

The half-strength MS media used in this study was solidified with $6.5 \mathrm{~g} \cdot \mathrm{L}^{-1}$ agar and the $\mathrm{pH}$ was adjusted to 5.7 before autoclaving at $121^{\circ} \mathrm{C}$ for $20 \mathrm{~min}$. Antibiotics were filter-sterilized and added when the autoclaved media was cooled to about $50^{\circ} \mathrm{C}$.

Agrobacterium inoculation of tobacco leaf explants and induction of hairy roots

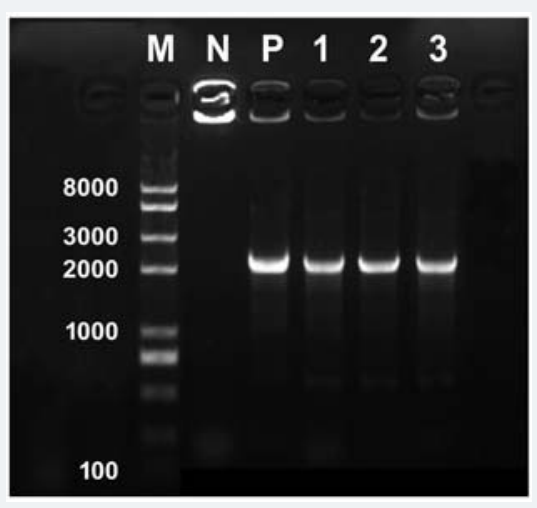

Figure 1: PCR confirmation of the putatively transformed single colonies of A. rhizogenes ATCC15834 with the binary vector $\mathrm{pBI}$ 121. Lane $\mathrm{M}$, DNA marker; lane $\mathrm{N}$, non-transformed colony as negative control; lane $\mathrm{P}$, plasmid DNA as positive control; lanes 1-3, kanamycin resistant single colonies. Expected size of the amplified fragment is 2239 base pairs. 
For the induction of hairy roots in tobacco leaf explants, lager culture of the transformed A. rhizogenes was prepared in LB broth containing antibiotic rifampicin and kanamycin (both at $50 \mathrm{mg} \cdot \mathrm{L}^{-1}$ ). Agrobacterium culture was grown to an $\mathrm{OD}_{600}$ value of around 0.6. The cells were then pelleted by centrifugation at $2100 \times \mathrm{g}$ for $10 \mathrm{~min}$, and the pellet was re-suspended in MS liquid medium to get a final $\mathrm{OD}_{600}$ value of 0.6 before inoculation.

Young tobacco leaves were excised from the in vitro grown plantlets and soaked in MS liquid media (4.4g. $\mathrm{L}^{-1}$ MS salts, $30 \mathrm{~g} \cdot \mathrm{L}^{-1}$ sucrose, $\mathrm{pH} 5.7$ ) in a sterile Petri dish to avoid de-hydration. The leaves were first punctured at several places using a sterile scalpel to facilitate Agrobacterium infection, and then cut into about $8 \times 10 \mathrm{~mm}$ rectangular pieces and placed into liquid MS media in a Petri dish. The explants were submerged in the Agrobacterium culture for $5 \mathrm{~min}$. Inoculated leaf pieces were blotted on sterile filter paper to remove excess Agrobacterium, and then plated to the halfstrength MS media supplemented with $30 \mathrm{~g} \cdot \mathrm{L}^{-1}$ sucrose for co-cultivation $\left(25^{\circ} \mathrm{C}\right.$ in the dark for 2days). Following co-cultivation, the leaf explants were rinsed 2 times with sterile distilled water to remove Agrobacterium, and then subjected to one additional rinses with MS liquid containing $500 \mathrm{mg} \cdot \mathrm{L}^{-1}$ carbenicillin. Afterwards, the explants were blotted on filter paper, and plated (adaxial side down, 10-15 explants.plate ${ }^{-1}$ ) into the media with different concentrations of kanamycin in combination with 300 $\mathrm{mg} \cdot \mathrm{L}^{-1}$ carbenicillin. Petri dishes were covered and well-sealed with a strip of parafilm. The cultures were incubated at $25 \pm 1^{\circ} \mathrm{C}$ with a $16 \mathrm{~h}$ photoperiod for the generation of hairy roots. The non-transformed wild-type Agrobacterium was used as control, and in this case, no kanamycin was used for the respective culturing.

\section{Data collection}

After four weeks of culturing, the individual hairy root lines were counted from each explant through destructive sampling. The mean data from all explants within a plate represented the data for one replication. In this way the data from replications of all treatments were collected. For this study, the treatments were compared by determining the mean number of hairy root lines generated per explant (i.e. hairy roots.explant ${ }^{-1}$ ).

\section{$\beta$-glucuronidase (GUS) expression assay in the hairy roots}

The histochemical assay for gusA gene expression was performed as previously described by Jefferson et al. [27]. In brief, the hairy roots were separated from the explants, submerged into GUS staining solution ( $1 \mathrm{mM} \mathrm{X-Gluc,} 50 \mathrm{mM}$ phosphate buffer, $10 \mathrm{mM}$ EDTA, and $0.1 \%$ Triton $\mathrm{x}-100$ ) and incubated for $12 \mathrm{~h}$ at $37^{\circ} \mathrm{C}$. The explants were soaked in $70 \%$ ethanol and examined for blue colour development.

\section{STATISTICAL ANALYSIS}

Results of hairy root generation were expressed as the mean value \pm standard deviation (SD). Data were analyzed using ANOVA, and statistical differences between means were compared by Duncan's multiple range test (DMRT), using the statistical package MSTAT [28].

\section{RESULTS AND DISCUSSION}

\section{Transformation of wild-type A. rhizogenes}

After several attempts, the binary vector pBI121 was successfully introduced into the $\mathrm{CaCl}_{2}$ competent $A$. rhizogenes ATCC15834 through heat shock method, which was confirmed by PCR and gel electrophoresis.

Comparative efficiency of the wild-type and transformed Agrobacterium in hairy root generation 
In order to compare the transformation efficiency of the wild-type and transformed A. rhizogenes, both the wild-type and transformed Agrobacterium were used to generate hairy roots from tobacco leaf explants. Hairy roots started to appear after about 9 days of inoculation. After about four weeks of inoculation, hairy roots were almost covered all the explants in T0 (Figure 2). Results showed that when the wildtype A. rhizogenes ATCC15834 was transformed with a second plasmid (pBI121), its virulence significantly decreased $(p<0.01)$, showing $6.95 \pm 0.76$ hairy roots $\cdot$ explant ${ }^{-1}$ in T1 compared to the T0 where the wild-type Agrobacterium generated $12.70 \pm 1.41$ hairy roots.explant ${ }^{-1}$ (Figure 2 and 3). This suggested that transfer of T-DNA from the Ri plasmid was significantly affected by the presence of the second plasmid and determination of the underlying reason will require further study.

\section{Hairy root generation efficiency under selection pressure}

To observe the hairy root generation efficiency of the transformed Agrobacterium under different selection pressures, different concentrations of kanamycin was used in the selection media. It was observed that number of hairy roots gradually decreased with increasing concentrations of the selection agent kanamycin (Figure 2). Significantly $(p<0.01)$ higher hairy roots per explant $(6.95 \pm 0.76)$ was obtained in T1 when no kanamycin was used (Figure 2 and 3). It was followed by $4.94 \pm 0.49$ hairy roots explant ${ }^{-1}$ in T2 $\left(12.5 \mathrm{mg} \cdot \mathrm{L}^{-1}\right.$ kanamycin), $2.86 \pm 0.80$ hairy roots explant ${ }^{-1}$ in T3 (25 mg. $\mathrm{L}^{-1}$ kanamycin), $1.83 \pm 0.39$ hairy roots $\cdot$ explant $^{-1}$ in T4 $\left(37.5 \mathrm{mg} \cdot \mathrm{L}^{-1}\right.$ kanamycin), and the lowest of $0.753 \pm 0.150$ hairy roots explant ${ }^{-1}$ in $\mathrm{T} 5\left(50 \mathrm{mg} \cdot \mathrm{L}^{-1}\right.$ kanamycin). However, the differences of efficiencies between T3 and T4, and in between T4 and T5 were not statistically significant $(p>0.05)$. In general, when the T-DNA of the Ri

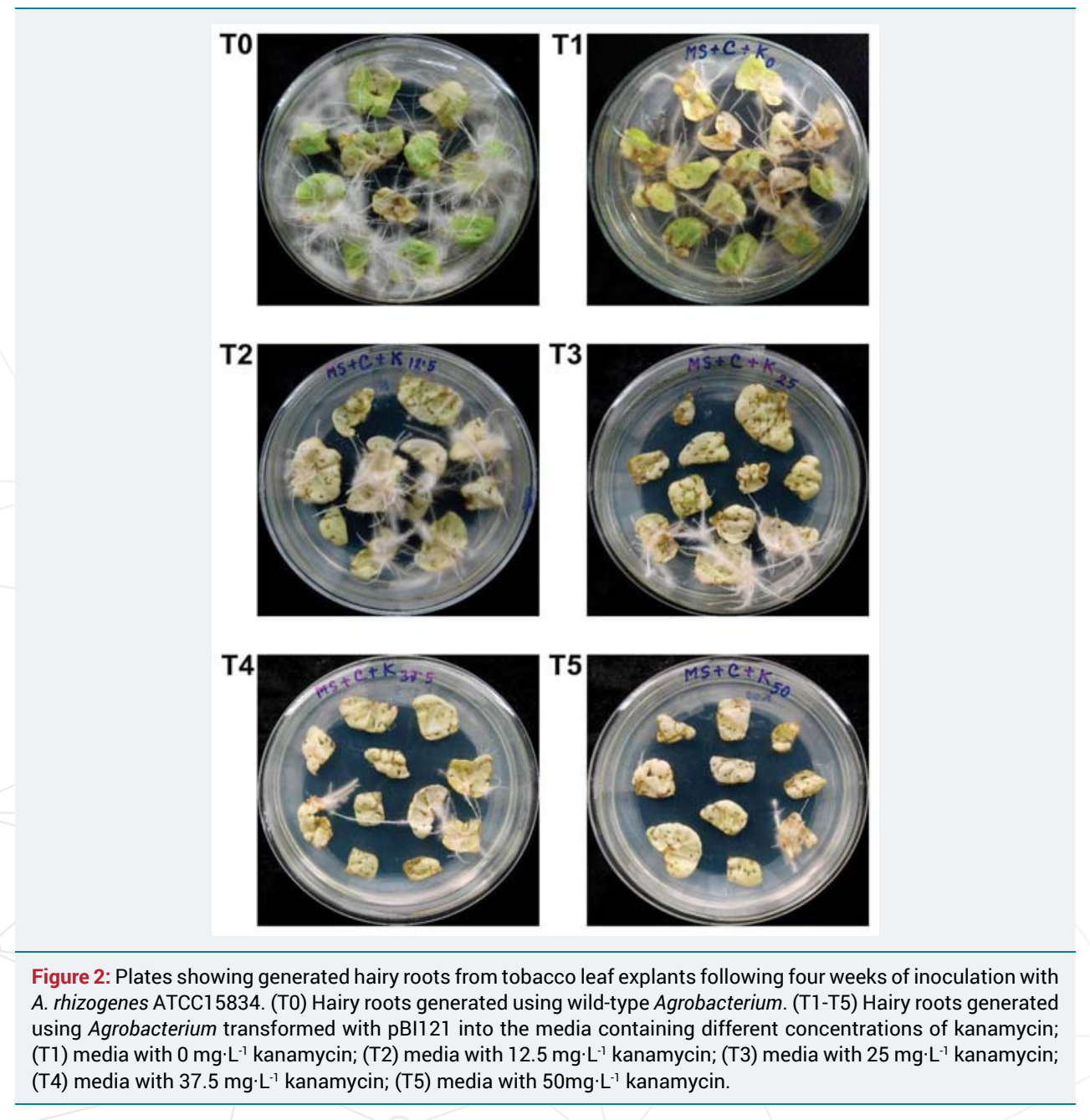




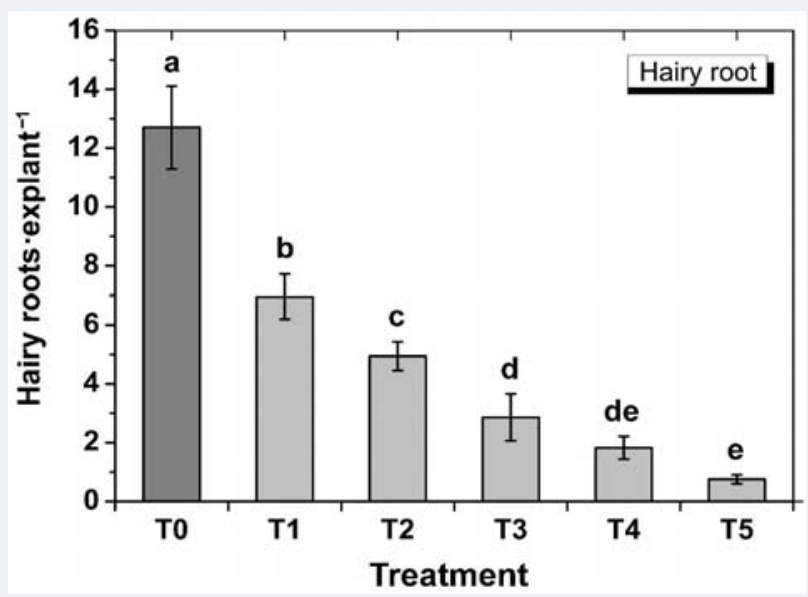

Figure 3: Effect of Agrobacterium type and kanamycin concentration of the selection media on the generation of hairy roots from tobacco leaf explants. T0, Wild-type Agrobacterium $+0 \mathrm{mg} \cdot \mathrm{L}^{-1}$ kanamycin; T1, transformed Agrobacterium+0mg $\mathrm{L}^{-1}$ kanamycin; T2, transformed Agrobacterium $+12.5 \mathrm{mg} \cdot \mathrm{L}^{-1}$ kanamycin; T3, transformed Agrobacterium+25.0 mg $\cdot \mathrm{L}^{-1}$ kanamycin; T4, transformed Agrobacterium $+37.5 \mathrm{mg} \cdot \mathrm{L}^{-1}$ kanamycin; T5, transformed Agrobacterium $+50 \mathrm{mg} \cdot \mathrm{L}^{-1}$ kanamycin. Data show the mean $\pm \mathrm{SD}(\mathrm{n}=3)$. Statistical significance was analyzed using ANOVA. Means followed by the same letter are not significantly different $(p>0.01)$.

plasmid is transferred into a plant cell and integrated into the genome, the hairy roots are supposed to be generated only from that transformed cell. If the same cell is also transformed simultaneously with a resistant gene from the binary vector, then the cotransformed cell will be capable of generating hairy roots under selection pressure. The results showing significantly reduced hairy roots in T2-T5 under selection pressure compared to that in T1 without any selection pressure, suggesting that cotransformation might has not always occurred. Crane et al. [23], also reported that not all hairy roots were the result of a co-transformation event. Again, Collier et al. [29], reported that between 20 and $60 \%$ of hairy roots produced on shoots inoculated with a wild-type $A$. rhizogenes containing a binary plasmid will contain both hairyroot-inducing and binary T-DNA. Considering these, the generated hairy roots were then tested for GUS expression to screen for genomic integration of the T-DNA from the pBI121 vector. Some hairy roots showed highly variable (very weak to strong) GUS expression (Figure 4) throughout the whole root; some showed very low levels only at the root tip, and others did not show any expression, even under variable selection pressures. The probable cause is that plant transformation does not always result in efficient transgene expression due to integration of T-DNA into transcriptionally silent regions of the plant genome [30]. These results suggest that fluorescent markers could be a better choice as an alternative to antibiotic selection, which seems to be more reliable than kanamycin resistance for screening the transgenic hairy roots where the transgene is efficiently expressed.

\section{CONCLUSION}

In this study, wild-type A. rhizogenes ATCC 15834 was successfully transformed with the binary vector pBI121, but compared to the wild-type, the transformed Agrobacterium showed reduced virulence. Hairy root generation efficiency of the transformed Agrobacterium was highest without any kanamycin in the media and lowest with $50 \mathrm{mg} \cdot \mathrm{L}^{-1}$ kanamycin. Some hairy roots showed GUS expression, confirming the genomic integration of transcriptionally active T-DNA, althought this was not always the case. Results of this study also suggested that fluorescent markers could be a better alternative to antibiotic selection, which seems to be more reliable than kanamycin resistance for screening the transgenic hairy roots with efficient transgene expression.

\section{ACKNOWLEDGMENTS}




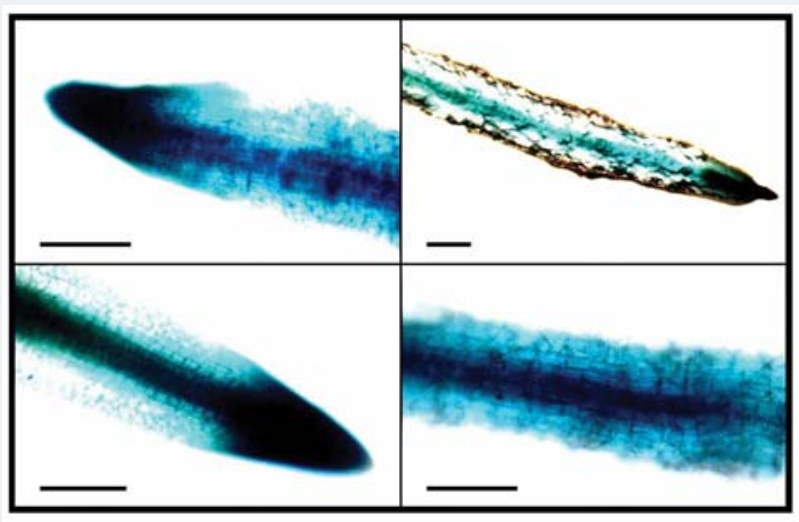

Figure 4: Stable GUS expression in hairy roots of tobacco leaf explants. Some hairy roots showed very high and some showed very low GUS expression even under the same selection pressure. Scale bar $=500 \mu \mathrm{m}$.

The author express his thanks to Liu Jing Jing for providing the wild-type tobacco seedlings for the experiment.

\section{REFERENCES}

1. Dunwell JM. Transgenic approaches to crop improvement. J Exp Bot. 2000; 51: 487-496. Ref.: https://goo.gl/RMeC4x

2. Ingelbrecht I, Breyne $P$, Vancompernolle $K$, Jacobs $A$, Van Montagu $M$, et al. Transcriptional interferences in transgenic plants. Gene. 1991; 109: 239-242. Ref.: https://goo.gl/4GSpst

3. Conn HJ. Validity of the genus Alcaligenes. J Bacteriol. 1942; 44: 353-360. Ref.: https://goo.gl/vYEOUl

4. Veena V, Taylor CG. Agrobacterium rhizogenes: recent developments and promising applications. In vitro Cell. 2007; 43: 383-403. Ref.: https://goo.gl/0Yuga3

5. Gelvin SB. Improving plant genetic engineering by manipulating the host. Trends Biotechnol. 2003; 21: 95-98. Ref.: https://goo.gl/pk440K

6. Chandra S. Natural plant genetic engineer Agrobacterium rhizogenes: role of T-DNA in plant secondary metabolism. Biotechnol Lett. 2012; 34: 407-415. Ref.: https://goo.gl/xewU9B

7. Chilton MD, Tepfer DA, Petit A, David C, Casse-Delbart F, et al. Agrobacterium rhizogenes inserts T-DNA into the genomes of the host plant root cells. Nature. 1982; 295: 432-434. Ref.: https://goo.gl/MWWaeV

8. Lee S, Blackhall NW, Power JB, Cocking EC, Tepfer D, et al. Genetic and morphological transformation of rice with the rolA gene from the Ri T-DNA of Agrobacterium rhizogenes. Plant Sci. 2001; 161: 917925. Ref.: https://goo.gl/g8NPV4

9. Rao SR, Ravishankar G. Plant cell cultures: chemical factories of secondary metabolites. Biotechnol Adv. 2002; 20: 101-153. Ref.: https://goo.gl/8GHsi4

10. Shanks JV, Morgan J. Plant 'hairy root' culture. Curr Opin Biotech. 1999; 10: 151-155. Ref.: https://goo.gl/t78704

11. Kim YJ, Wyslouzil BE, Weathers PJ. Secondary metabolism of hairy root cultures in bioreactors. In vitro Cell. 2002; 38: 1-10. Ref.: https://goo.gl/6wQP7d

12. Nader BL, Taketa AT, Pereda-Miranda R, Villarreal ML. Production of triterpenoids in liquid-cultivated hairy roots of Galphimia glauca. Planta Med. 2006; 72: 842-844. Ref.: https://goo.gl/5b4uVk

13. Bensaddek L, Villarreal ML, Fliniaux MA. Induction and growth of hairy roots for the production of medicinal compounds. Electron J Integr Biosci. 2008; 3: 2-9. Ref.: https://goo.gl/mtl0Jv

14. Hamill JD, Prescott A, Martin C. Assessment of the efficiency of cotransformation of the T-DNA of disarmed binary vectors derived from Agrobacterium tumefaciens and the T-DNA of $A$. rhizogenes. Plant Mol Biol. 1987; 9: 573-584. Ref.: https://goo.gl/wSN8Cp

15. Limpens E, Ramos J, Franken C, Raz V, Compaan B, et al. RNA interference in Agrobacterium 
rhizogenes-transformed roots of Arabidopsis and Medicago truncatula. J Exp Bot. 2004; 55: 983992. Ref.: https://goo.gl/lorYQ3

16. Preiszner J, van Toai TT, Huynh L, Bolla RI, Yen HH. Structure and activity of a soybean Adh promoter in transgenic hairy roots. Plant Cell Rep. 2001; 20: 763-769. Ref.: https://goo.gl/I9qGRm

17. Menzel G, Harloff HJ, Jung C. Expression of bacterial poly (3-hydroxybutyrate) synthesis genes in hairy roots of sugar beet (Beta vulgaris L.). Appl Microbiol Biot. 2003; 60: 571-576. Ref.: https://goo.gl/LGVWec

18. Sharp JM, Doran PM. Strategies for enhancing monoclonal antibody accumulation in plant cell and organ cultures. Biotechnol Progr. 2001; 17: 979-992. Ref.: https://goo.gl/lrFcdz

19. Mitra A, Mayer MJ, Mellon FA, Michael AJ, Narbad A, et al. 4-hydroxycinnamoyl-CoA hydratase/lyase, an enzyme of phenylpropanoid cleavage from Pseudomonas, causes formation of $\mathrm{C} 6-\mathrm{C} 1$ acid and alcohol glucose conjugate when expressed in hairy root of Datura stramonium L. Planta. 2002; 215 : 79-89. Ref.: https://goo.gl/1VGMmL

20. Seki H, Ohyama K, Nishizawa T, Yoshida S, Muranaka T. The "all-in-one" rol-type binary vectors as a tool for functional genomics studies using hairy roots. Plant Biotechnol. 2008; 25: 347-355. Ref.: https://goo.gl/OOLBX2

21. Hansen J, Jurgensen JE, Stougaard J, Marcker KA. Hairy roots-a short cut to transgenic root nodules. Plant Cell Rep. 1989; 8: 12-15. Ref.: https://goo.gl/b2g1lo

22. Ohara A, Akasaka $Y$, Daimon $\mathrm{H}$, Mii M. Plant regeneration from hairy roots induced by infection with Agrobacterium rhizogenes in Crotalaria juncea L. Plant Cell Rep. 2000; 19: 563-568. Ref.: https://goo.gl/OXIdKC

23. Crane C, Wright E, Dixon RA, Wang ZY. Transgenic Medicago truncatula plants obtained from Agrobacterium tumefaciens-transformed roots and Agrobacterium rhizogenes-transformed hairy roots. Planta. 2006; 223: 1344-1354. Ref.: https://goo.gl/1jgvba

24. Vinterhalter B, Savic J, Platis AJ, Raspor M, Ninkovic S, et al. Nickel tolerance and hyperaccumulation in shoot cultures regenerated from hairy root cultures of Alyssum murale Waldst et Kit. Plant Cell Tiss Org. 2008; 94: 299-303. Ref.: https://goo.gl/V29PAh

25. Gangopadhyay M, Chakraborty D, Bhattacharyya S, Bhattacharya S. Regeneration of transformed plants from hairy roots of Plumbago indica. Plant Cell Tiss Org. 2010; 102: 109-114. Ref.: https://goo.gl/rUDdH7

26. Hatamoto $H$, Boulter ME, Shirsat AH, Croy EJ, Ellis JR. Recovery of morphologically normal transgenic tobacco from hairy roots co-transformed with Agrobacterium rhizogenes and a binary vector plasmid. Plant Cell Rep. 1990; 9: 88-92. Ref.: https://goo.gl/db0C4H

27. Jefferson RA, Kavanagh TA, Bevan MW. GUS fusions: Beta-glucuronidase as a sensitive and versatile gene fusion marker in higher plants. EMBO J. 1987; 6: 3901-3907. Ref.: https://goo.gl/k2ea7Q

28. Russell OF. MSTAT-C v. 2.1 (A Computer Based Data Analysis Software); Crop and Soil Science Department, Michigan State University: East Lansing, MI, USA. 1994.

29. Collier R, Fuchs B, Walter N, Kevin LW, Taylor CG. Ex vitro composite plants: an inexpensive, rapid method for root biology. Plant J. 2005; 43: 449-457. Ref.: https://goo.gl/Vtllx7

30. Kakkar A, Verma VK. Agrobacterium mediated biotransformation. J Appl Pharmaceut Sci. 2011; 01: 29-35. Ref.: https://goo.gl/ae6Vi9 